\title{
Stanje radne snage u šumarstvu Federacije Bosne i Hercegovine
}

\author{
David Mijoč, Mario Šporčić, Matija Landekić
}

\begin{abstract}
Nacrtak - Abstract
U radu se prikazuju neka stajališta o stanju radne snage u šumarstou Federacije Bosne $i$ Hercegovine (FBiH). Rezultati su dobiveni na temelju ispitivanja šumarskih stručnjaka $i$ šumskih radnika vezano uz ocjenu glavnih obilježja i položaja radne snage u šumarstou $F B i H$, zatim njihova stajališta o pitanju nedostatka šumskih radnika, promišljanja o mogućnostima $i$ načinima snažnijega regrutiranja $i$ zadržavanja radnika u šumarstou te osiguranja veće predanosti šumskih radnika njihovu poslu. Istraživanje je provedeno u trima županijama FBiH (Hercegbosanska, Srednjobosanska, Unsko-sanska), a uzorkom ispitanika $(N=184)$ obuhvatilo je tri razine - osobnu (šumski radnici), razinu poduzeća (šumarske tortke) te institucionalnu (šumarska uprava). Rezultati istraživanja pokazuju prosječnu dob šumskih radnika od 44 godine te veliku većinu ispitanika (96\%) koji nedostatak radne snage smatraju vrlo izraženim i sve više rastućim problemom u šumarstou FBiH. Odlazak radno sposobnoga stanovništva izvan $\mathrm{FBiH}$ za $93 \%$ ispitanika glavni je razlog nedostatka šumskih radnika. S obzirom na to da je riječ o vrlo složenom problemu, održivost kvalitetne radne snage u šumarstou FBiH pitanje je koje traži sustavan pristup $i$ aktivno sudjelovanje svih uključenih dionika, u proom redu državnih i obrazovnih institucija, šumarskih poduzeća, sindikata i ostalih važnih interesnih skupina. Rezultati ovoga istraživanja mogu pridonijeti definiranju polazišta značajnih u iznalaženju učinkovitih strategija regrutiranja i zadržavanja šumskih radnika te postizanju održive radne snage u šumarstou FBiH.
\end{abstract}

Ključne riječi: šumarstvo, šumski radnici, nedostatak radne snage, regrutiranje radnika, Federacija Bosne i Hercegovine

\section{Uvod - Introduction}

Kvalitetna, stručno osposobljena i održiva radna snaga temeljni je preduvjet za uspješnu proizvodnju u šumarstvu i održivo gospodarenje šumama (Šporčić i dr. 2015). Rad u šumarstvu, po mnogim pokazateljima, jedna je od najtežih i najrizičnijih profesija, s brojnim nesrećama pri obavljanju posla, visokim udjelom smrtnih ozljeda i učestalim profesionalnim bolestima (EU-OSHA 2008, Adams i dr. 2014, Musić i dr. 2019). Zbog rada u prirodnom okruženju, visokih fizičkih opterećenja, učestale upotrebe ručnih alata i strojeva radnici su izloženi značajnim fizičkim, psihološkim i okolišnim čimbenicima, odnosno njihovu nepovoljnomu utjecaju (Landekić i dr. 2013, 2019, Bačić i dr. 2018). Mlađi naraštaji danas često rad u šumarstvu, posebno poslove sjekača, traktorista, kopčaša i sl., doživljavaju kao
3D poslove (engl. Dirty, Dangerous, Demeaning) te ih opisuju prljavim, opasnim i ponižavajućim. Prema tomu kao značajne teškoće posljednjih se godina javljaju manjak interesa za rad u šumarstvu, nedostatak proizvodnih radnika, otežano osposobljavanje i zadržavanje šumskih radnika, visoka dob i loše zdravstveno stanje radnika, otežani uvjeti rada i sl. (Landekić i dr. 2017). O šumskim se radnicima također često govori kao o specifičnoj supkulturi koja je u društvu prilično marginalizirana, što samu profesiju čini neatraktivnom i što otežava pronalaženje ljudi koji bi bili zainteresirani za te poslove (Glavonjić 2016, Błuszkowska i Nurek 2014).

$\mathrm{U}$ širem smislu strukturne promjene prisutne $\mathrm{u}$ svijetu i Europi poput globalizacije, iseljavanja ruralnih područja, starenje populacije nesumnjivo utječu i na šumarski sektor i na radnu snagu u sektoru. Prema FAO/UNECE (2020) ukupan broj šum- 
skih radnika u Europi u razdoblju 2008-2016. godine smanjio se za $18 \%$. U skandinavskim zemljama i Njemačkoj smanjenje broja šumskih radnika uglavnom je uzrokovano značajnijom mehanizacijom radova. U Švedskoj je tako broj šumskih radnika od 1960-ih do 2000. smanjen za 90 \% (Axelsson 1998). U Francuskoj, unatoč zapošljavanju stranih radnika, broj je sjekača od 2004. do 2015. godine kontinuirano padao u prosjeku za 400 radnika godišnje. Kao posljedica toga postupno se uvodila mehanizirana sječa, broj harvestera povećan je za $40 \%$, a razvoj je mehanizacije istaknut kao glavni izazov u ublažavanju negativnoga utjecaja nedostatka radne snage (Cacot i dr. 2015). U Grčkoj Tsioras $(2010,2012)$ ističe problem nezadovoljstva šumskih radnika zbog niskih primanja, financijske nesigurnosti, sezonalnosti posla i fizički teškoga rada te navodi da $85 \%$ šumarskih stručnjaka smatra da će u budućnosti biti znatnih problema s nedostatkom radne snage. U SAD-u Egan i Taggart (2004) zaključuju da gotovo $70 \%$ sjekača u šumama Nove Engleske ne želi taj posao preporučiti svojoj djeci, iako su i sami potekli iz šumarskih obitelji. Salminen i dr. (1999) navode da se broj šumskih radnika u Finskoj od 1990 do 1995. godine smanjio za $50 \%$.

Postojeću radnu snagu u šumarstvu također obilježava nepovoljna dobna struktura. Udio šumskih radnika starijih od 50 godina $\mathrm{u}$ Europi se u razdoblju 2000-2010. godine povećao za $30 \%$. U Švedskoj, na primjer, polovica svih radnika do 2010. godine bila je $\mathrm{u}$ dobi od 50 i više godina. U zemljama kao što su Francuska, Njemačka, Irska i Norveška broj radnika starijih od 50 godina u istom se razdoblju povećao za preko $15 \%$ i doseže udio između $37 \%$ i $46 \%$ ukupne šumarske radne snage (FAO/UNECE 2020). Za razdoblje od 2015. do 2060. godine ističe se da će najveći utjecaj na demografiju i radnu snagu Europe, posebno u šumarstvu i ostalim manje atraktivnim sektorima, imati opće starenje populacije (Nair 2004, Ackerknecht 2010).

U Bosni i Hercegovini, kao i u ostalim zemljama u okruženju, prijelazom na tržišnu ekonomiju krajem 20. stoljeća značajno se smanjio broj zaposlenika i radnih sredstava u mnogim šumarskim upravama i poduzećima kojima je povjereno gospodarenje $\mathrm{dr}$ žavnim šumama. Paralelno se nije dogodila značajnija mehanizacija radova te je ručno-strojna razina mehaniziranja radova i dalje ostala najrasprostranjenija. Isto razdoblje okarakterizirao je razvoj novih poslovnih segmenata, kao što je pojava privatnih poduzetnika koji su postali nezaobilazni dio u pridobivanju drva i u drugim šumskim radovima (Šporčić i dr. 2009). Međutim, povremeno i kratkoročno angažiranje, tj. obujam ugovorenih radova, u većini slučajeva šumarskim poduzetnicima nije omogućilo dugoročno perspekti- vu i planiranje te njihov razvoj u stabilne subjekte $\mathrm{s}$ velikim brojem zaposlenika i visokim socijalnim i sigurnosnim standardima. Glavna obilježja toga dijela radne snage $u$ šumarstvu uglavnom su nedostatak ili tek ograničena skrb za radnike, niske plaće, nedovoljna socijalna zaštita, sezonsko zapošljavanje, loša izobrazba i dr. (Šporčić i dr. 2018). To čini zanimanje za rad u šumarstvu sve manjim, postojeću radnu snagu sve ranjivijom i imidž šumarstva sve lošijim. Glavonjić (2016) slično upozorava da se šumarstvo na Balkanu i u središnjoj Europi zbog niskih plaća i opasnih radnih uvjeta percipira kao nepoželjno zanimanje.

$S$ obzirom na navedeno, neosporno je da se šumarski sektor suočava s velikim izazovom privlačenja i zadržavanja šumskih radnika te postizanja potrebne održive radne snage u sektoru. To je svakako vrlo složeno pitanje koje traži sustavan pristup i aktivno sudjelovanje svih uključenih dionika, ponajprije državnih i obrazovnih institucija, šumarskih poduzeća, sindikata i ostalih važnih interesnih skupina. Omogućavanje sigurnijih, bolje plaćenih poslova i zadovoljniji radnici ključ su u ostvarivanju takvih zadaća. Cilj provedenoga istraživanja bio je dati preliminarne rezultate o položaju i statusu radne snage $u$ Federaciji Bosne i Hercegovine (FBiH), društveno-ekonomskim značajkama, stavu prema profesiji šumskoga radnika, mogućnostima unapređenje šumskoga rada i sl. Ispitivanja bi trebala pokazati koliko je problem nedostatka radne snage u FBiH doista ozbiljan, koje su mogućnosti i najbolji načini za snažnije regrutiranje i zadržavanje šumskih radnika te koje su najučinkovitije mjere za osiguranje veće predanosti radnika poslu. Rezultati istraživanja tako mogu pridonijeti $u$ definiranju polazišta značajnih u iznalaženju učinkovitih strategija privlačenja i zadržavanja šumskih radnika te postizanju održive radne snage $\mathrm{u}$ šumarstvu $\mathrm{FBiH}$. Predmetna istraživanja planiraju se provesti na cjelokupnom području $\mathrm{FBiH}$, a u ovom će se radu prikazati prve spoznaje dobivene na temelju ispitivanja provedenih u trima odabranim županijama FBIH.

\section{Materijal i metode-Material and methods}

Istraživanje je provedeno $\mathrm{u}$ trima županijama FBiH: Hercegbosanskoj županiji (HBŽ), Srednjobosanskoj županiji (SBŽ) i Unsko-sanskoj županiji (USŽ) (slika 1). U svakoj županiji gospodarenje državnim šumama povjereno je zasebnomu šumskogospodarskomu društvu, tj. državnomu šumarskomu poduzeću. Osim državnih, javnih šumarskih poduzeća u svakoj županiji djeluje i određeni broj 
privatnih poduzeća (poduzetnika) za izvođenje šumskih radova te zasebne institucije i tijela državne šumarske uprave. Istraživanja su uzorkom ispitanika obuhvatila sva tri navedena segmenta šumarstva odabranih županija.

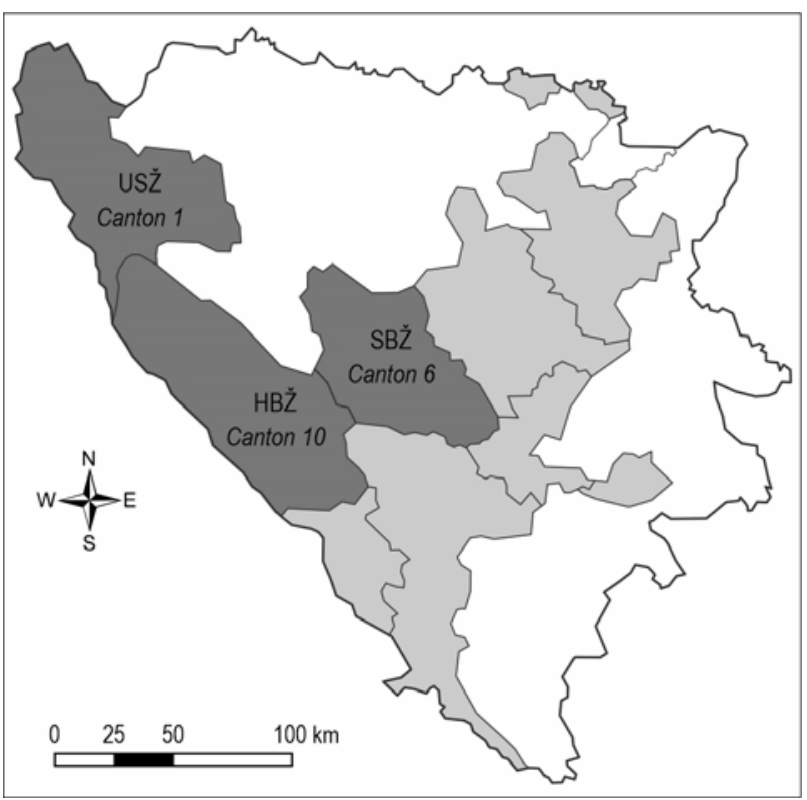

Slika 1. Područje istraživanja

Fig. 1 Research area

Ispitanici su u istraživanju bili šumski radnici zaposleni u javnim i privatnim šumarskim poduzećima te šumarski stručnjaci zaposleni u praksi (šumarska poduzeća), u institucijama i tijelima državne šumarske uprave. Tako je preko definiranih skupina ispitanika obuhvatilo tri razine - osobnu (šumski radnici), razinu poduzeća (javne i privatne šumarske tvrtke) te institucionalnu (županijska ministarstva i uprave za šume, sindikati, inspektorat i sl.).

Istraživanje je provedeno primjenom metode anketiranja, pri čemu je upotrijebljen posebno oblikovani anketni upitnik. Anketni upitnik oblikovan je na temelju spoznavanja literaturne dimenzije predmeta istraživanja te prethodnih razgovora $\mathrm{i}$ konzultacija s osobama izravno uključenim i dobro upoznatim s poslovima i problemima šumarske proizvodnje u FBiH. Anketni upitnik podijeljen je u tri cjeline - prva obuhvaća opće podatke o ispitanicima, druga se odnosi na značajke i specifičnosti rada u šumarstvu, a treća cjelina obuhvaća pitanja o nedostatku radne snage te regrutiranju i zadržavanju radnika u šumarstvu FBiH. Prve dvije cjeline upitnika razlikuju se za svaku pojedinu razinu ispitanika, dok je treća, najopsežnija cjelina upitnika, identična za sve tri razine, tj. skupine ispitanika.
Ispitivanje je provedeno u prvoj polovici 2021. godine. Upitnici su na sve razine ispitanika odaslani u tiskanoj formi te dodatno u digitalnoj formi (Googleovi obrasci) preko e-pošte i drugih komunikacijskih sredstava (Whatsapp, Viber, Telegram i sl.) u šumarska poduzeća i institucije. Do šumskih radnika $\mathrm{i}$ ostalih zaposlenika $\mathrm{u}$ šumarskim tvrtkama upitnici su distribuirani uz pomoć izvršnih direktora u državnim šumskogospodarskim društvima. Time se namjeravao postići što bolji odaziv ispitanika na anketu. Uzorak ispitanika, tj. veličina obuhvata, određen je tako da je u svakoj županiji na ispunjavanje upućeno: 75 upitnika za šumske radnike (sjekači, traktoristi, kopčaši i dr.), 40 upitnika za šumarske tvrtke (poslovođe, rukovoditelji, upravitelji) i 10 upitnika za institucije (stručnjaci ministarstava i uprava za šume, sindikati, inspektorat).

Nakon prikupljanja podataka izrađena je osnovna baza za unos svih prikupljenih podataka u MS Accessu. Za sistematizaciju te primarnu obradu i analizu prikupljenih podataka dodatno je korišten programski paket MS Excel. U analizi podataka primijenjena je deskriptivna statistika, a rezultati su prikazani tablično i grafički.

\section{Rezultati - Results}

Na odaslane upitnike (ukupno 375 upitnika u tiskanoj formi) primljeno je ukupno 184 odgovora (49 $\%$ ). Najbolji odaziv ostvaren je u županiji HBŽ (64,8\%),

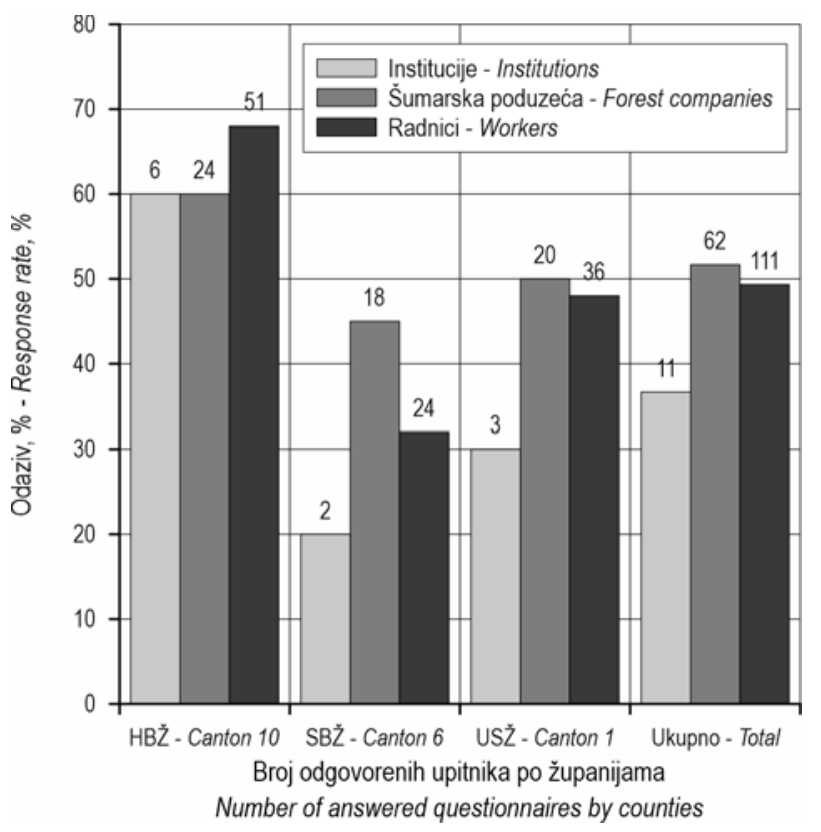

Slika 2. Struktura uzorka ispitanika na razini županija Fig. 2 Structure of respondents sample at canton level 
zatim u USŽ $(47,2 \%)$ te SBŽ $(35,2 \%)$. S obzirom na pojedine skupine ispitanika stručnjaci u šumarskim poduzećima ispunili su 51,7 \% njima odaslanih upitnika, šumski radnici 49,3\% upitnika, a stručnjaci u institucijama 36,7\% upitnika. Struktura uzorka ispitanika, tj. odgovorenih upitnika, prikazana je na slici 2.

\subsection{Osnovni podaci o radnicima - Basic information about workers}

Životna dob ispitanih radnika u prosjeku iznosi 43,8 godina, dok je medijana 46 godina. Oko $14 \%$ radnika mlađe je od 30 godina, dok se $52 \%$ radnika nalazi u dobi iznad 45 godina života (slika 3). Između prosječne dobi radnika zaposlenih u javnim poduzećima i onih zaposlenih kod privatnika postoji uočljiva razlika. Šumski radnici u javnim poduzećima u prosjeku su stariji za 8,4 godine. Između promatranih županija također je utvrđena određena razlika te su radnici u USŽ u prosjeku najstariji (48,5 godina).

Prema spolu svi su radnici muškarci, $85 \%$ ih živi u naseljima veličine ispod 5000 stanovnika, $58 \%$ ih ima završenu srednju školu, dok $35 \%$ ima samo osnovnoškolsko obrazovanje.

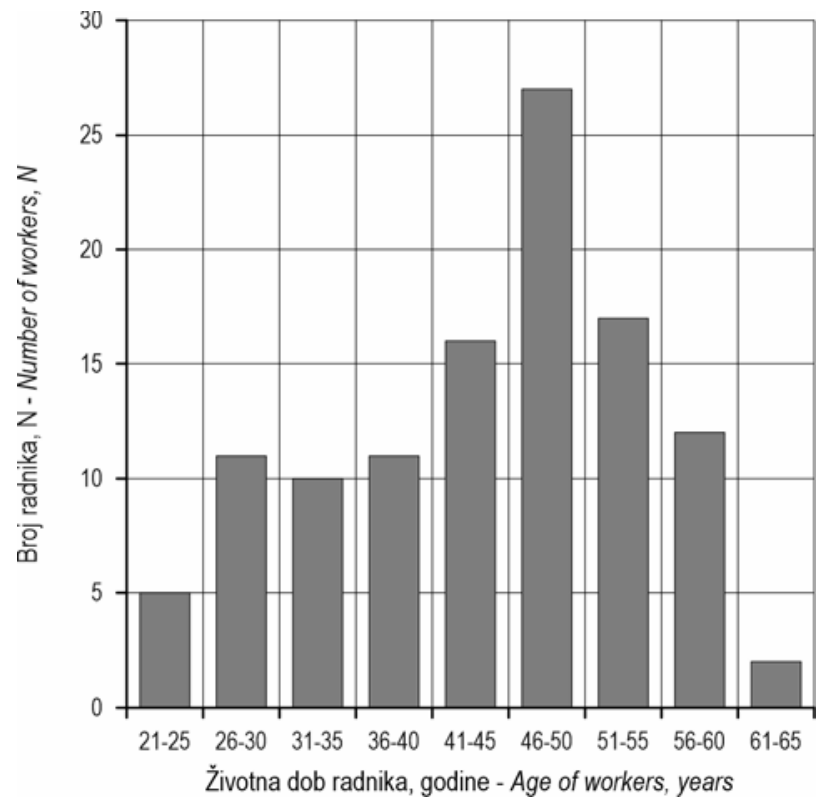

Slika 3. Raspodjela šumskih radnika prema životnoj dobi

Fig. 3 Distribution of forest workers by age

S obzirom na poslodavca $68 \%$ radnika, tj. primljenih upitnika, iz privatnih je šumarskih poduzeća, $31 \%$ iz javnih poduzeća, a $1 \%$ ima vlastiti obrt ili poduzeće za šumske radove. Oko $76 \%$ ispitanih radnika zaposleno je na neodređeno vrijeme, dok 24
$\%$ ima sklopljen ugovor o radu na određeno vrijeme. U privatnim šumarskim poduzećima gotovo trećina radnika zaposlena je na određeno vrijeme.

Većina radnika zaposlena je na radnom mjestu sjekača $(55 \%)$, zatim traktorista $(32 \%)$, kopčaša $(9 \%)$ ili ostalih poslova (4\%). Ukupno $31 \%$ radnika članovi su sindikata, pri čemu se to uglavnom odnosi na radnike zaposlene $\mathrm{u}$ javnim poduzećima.

\subsection{Stajališta radnika o vlastitoj profesiji - Workers' attitude to their occupation}

U nastavku su prikazana neka stajališta radnika vezano uz rad u šumarstvu, odabir zanimanja, njihove planove i očekivanja, perspektivu profesije šumskoga radnika i sl. Tablice 1 i 2 sadrže odabrana pitanja iz upitnika i udjele odgovora koje su radnici birali pri ispitivanju.

Tablica 1. Stavovi šumskih radnika vezani uz njihovo zanimanje Table 1 Forest workers' attitude to their occupation

\begin{tabular}{|c|c|c|c|}
\hline Pitanje - Question & Odgovor - Answer & $\mathrm{N}$ & $\%$ \\
\hline \multirow{4}{*}{$\begin{array}{l}\text { Posao u šumarstvu } \\
\text { odabrao sam iz } \\
\text { sljedećega razloga } \\
\text { I choose this job } \\
\text { because }\end{array}$} & $\begin{array}{l}\text { Nisam mogao naći drugi posao } \\
\text { I could not find other job }\end{array}$ & 43 & 38,7 \\
\hline & $\begin{array}{l}\text { Moj se otac bavio istim poslom } \\
\text { My father did the same job }\end{array}$ & 33 & 29,7 \\
\hline & $\begin{array}{l}\text { Posao mi se sviđa i cijenim taj rad } \\
\text { I like this job and I appriceate it }\end{array}$ & 20 & 18,0 \\
\hline & $\begin{array}{l}\text { Posao je izazovan i dobro plaćen } \\
\text { The job is challenging and well paid }\end{array}$ & 15 & 13,5 \\
\hline \multirow{4}{*}{$\begin{array}{l}\text { Zbog posla koji } \\
\text { radim osobno se } \\
\text { osjećam } \\
\text { Because of } \\
\text { the work I do, I } \\
\text { personally feel }\end{array}$} & Vrlo zadovoljno - Very satisfied & 6 & 5,4 \\
\hline & Zadovoljno - Satisfied & 72 & 64,9 \\
\hline & Ravnodušno - Indifferent & 22 & 19,8 \\
\hline & Nezadovoljno - Dissatisfied & 11 & 9,9 \\
\hline \multirow{5}{*}{$\begin{array}{l}\text { Koji je glavni } \\
\text { nedostatak vašeg } \\
\text { posla? } \\
\text { What is the main } \\
\text { disadvantage of } \\
\text { your job? }\end{array}$} & $\begin{array}{l}\text { Fizički težak rad } \\
\text { Physically hard work }\end{array}$ & 62 & 55,9 \\
\hline & $\begin{array}{l}\text { Velika udaljenost od kuće i obitelji } \\
\text { Great distance from house and family }\end{array}$ & 14 & 12,6 \\
\hline & $\begin{array}{l}\text { Slabo cijenjen i loše plaćen posao } \\
\text { Low valued and poorly paid job }\end{array}$ & 11 & 9,9 \\
\hline & $\begin{array}{l}\text { Opasan posao s čestim ozljedama } \\
\text { Dangerous job with frequend injuries }\end{array}$ & 23 & 20,7 \\
\hline & Nema odgovora - No answer & 1 & 0,9 \\
\hline \multirow{4}{*}{$\begin{array}{l}\text { Svojoj bih djeci } \\
\text { preporučio ovaj } \\
\text { posao } \\
\text { I would recomend } \\
\text { this job to my } \\
\text { children }\end{array}$} & Da, uvijek - Yes, always & 2 & 1,8 \\
\hline & $\begin{array}{l}\text { Da, kada bi bili bolji uvjeti } \\
\text { Yes, if conditions were better }\end{array}$ & 12 & 10,8 \\
\hline & Nikada - Never & 87 & 78,4 \\
\hline & Svejedno mi je - I do not care & 10 & 9,0 \\
\hline \multirow{3}{*}{$\begin{array}{l}\text { Kada bih mogao } \\
\text { birati poslodavca, } \\
\text { najradije bih odabrao } \\
\text { If I could choose an } \\
\text { employer, I would } \\
\text { prefer to choose }\end{array}$} & $\begin{array}{l}\text { Javno poduzeće } \\
\text { Public company }\end{array}$ & 76 & 68,5 \\
\hline & $\begin{array}{l}\text { Privatno poduzeće } \\
\text { Private company }\end{array}$ & 13 & 11,7 \\
\hline & $\begin{array}{l}\text { Vlastiti obrt / poduzeće } \\
\text { To have my own company }\end{array}$ & 22 & 19,8 \\
\hline
\end{tabular}


Između dobivenih odgovora ističe se da je većina ispitanika (39\%) odabrala posao šumskoga radnika jer nije mogla naći drugo zaposlenje. $S$ druge strane velika većina $(65 \%)$ zbog posla koji obavlja osjeća se relativno zadovoljno. Glavnim nedostatkom svojega posla radnici smatraju težak fizički rad (56\%), a $78 \%$ njih taj posao nikada ne bi preporučilo svojoj djeci. Kao poslodavca radnici bi radije odabrali javno poduzeće ispred privatnoga šumarskoga poduzeća (68 $\%$ ). Pritom, među zaposlenima u javnom poduzeću, $9 \%$ radnika željelo bi voditi vlastiti obrt ili poduzeće, a ni jedan radnik ne bi prešao kod privatnoga poslodavca. S druge strane $25 \%$ radnika zaposlenih u privatnom poduzeću željelo bi imati vlastiti obrt ili poduzeće, dok bi ih $17 \%$ željelo ostati zaposleno kod privatnoga poduzetnika.

Tablica 2. Stavovi šumskih radnika o perspektivi njihova posla Table 2 Forest workers' attitude to their job prospects

\begin{tabular}{|c|c|c|c|}
\hline Pitanje - Question & Odgovor - Answer & $\mathrm{N}$ & $\%$ \\
\hline \multirow{5}{*}{$\begin{array}{l}\text { Kada bih mogao } \\
\text { promijeniti posao, } \\
\text { odabrao bih nešto } \\
\text { drugo } \\
\text { If I could change } \\
\text { the job, I would } \\
\text { choose something } \\
\text { else }\end{array}$} & $\begin{array}{l}\text { Da, volio bih raditi nešto drugo } \\
\text { Yes, I would like to do something } \\
\text { else }\end{array}$ & 50 & 45,0 \\
\hline & $\begin{array}{l}\text { Ne, ponovno bih odabrao isti posao } \\
\text { No, I would choose the same job } \\
\text { again }\end{array}$ & 50 & 45,0 \\
\hline & $\begin{array}{l}\text { Trenutno tražim drugi posao } \\
\text { I am currently looking for another job }\end{array}$ & 5 & 4,5 \\
\hline & $\begin{array}{l}\text { U postupku sam odlaska s ovoga } \\
\text { posla } \\
\text { I am in the process of leaving this job }\end{array}$ & 4 & 3,6 \\
\hline & $\begin{array}{l}\text { Bez odgovora } \\
\text { No answer }\end{array}$ & 2 & 1,8 \\
\hline \multirow{4}{*}{$\begin{array}{l}\text { Razmišljam o } \\
\text { odlasku iz BiH i } \\
\text { traženju posla u } \\
\text { nekoj drugoj državi } \\
\text { I am thinking about } \\
\text { leaving B\&H and } \\
\text { looking for a job } \\
\text { abroad }\end{array}$} & $\begin{array}{l}\text { Da, radio bih ovaj isti posao } \\
\text { Yes, I would do the same job }\end{array}$ & 11 & 9,9 \\
\hline & $\begin{array}{l}\text { Da, ali na neki drugi posao } \\
\text { Yes, but for another job }\end{array}$ & 31 & 27,9 \\
\hline & $\begin{array}{l}\text { Da, na isti posao, ali za veću plaću } \\
\text { Yes, the same job but for a higher } \\
\text { salary }\end{array}$ & 26 & 23,4 \\
\hline & $\begin{array}{l}\text { Ne, ovdje mi je dobro } \\
\text { No, I am fine here }\end{array}$ & 43 & 38,7 \\
\hline \multirow{4}{*}{$\begin{array}{l}\text { Moj će se položaj } \\
\text { na radu u sljedećih } \\
\text { nekoliko godina } \\
\text { My position at work } \\
\text { in the next few } \\
\text { years will }\end{array}$} & $\begin{array}{l}\text { Poboljšati } \\
\text { Improve }\end{array}$ & 37 & 33,3 \\
\hline & $\begin{array}{l}\text { Neće se mijenjati } \\
\text { Not change }\end{array}$ & 61 & 55,0 \\
\hline & $\begin{array}{l}\text { Pogoršati } \\
\text { Aggravate }\end{array}$ & 12 & 10,8 \\
\hline & $\begin{array}{l}\text { Bez odgovora } \\
\text { No answer }\end{array}$ & 1 & 0,9 \\
\hline
\end{tabular}

Iz tablice 2 vidljivo je da vrlo mali broj radnika aktivno traži drugo zaposlenje (5\%), ili je u procesu odlaska s trenutačnoga posla (4\%). Oko $45 \%$ radnika iskazuje želju za nekom drugom vrstom zaposlenja, a jednako toliko ih tvrdi da bi ponovno odabrali isti posao i kada bi ga mogli promijeniti. Više od polovice ispitanih radnika (61 \%) razmišlja o odlasku iz BiH i traženju istoga ili nekoga drugoga posla u drugoj državi. S obzirom na odlazak izvan $\mathrm{BiH}$ između pojedinih dobnih skupina radnika nisu uočene značajnije razlike. Međutim, s obzirom na poslodavca, utvrđeno je da $71 \%$ zaposlenih kod privatnika razmišlja o napuštanju zemlje, dok je udio istomišljenika koji rade u javnom poduzeću gotovo dvostruko manji.

\subsection{Stajališta o pitanju nedostatka radne snage u šumarstvu - Attitudes on the issue of labour shortage in forestry}

O pitanju nedostatka radne snage $\mathrm{u}$ šumarstvu svoja su stajališta iskazale sve tri skupine ispitanika. Prikupljena stajališta o izraženosti toga problema, mogućnostima regrutiranja i zadržavanja radnika te osiguranja veće predanosti poslu prikazuju se u nastavku rada. Temeljno pitanje pritom je nedostaje li u šumarstvu FBiH stručnih i osposobljenih radnika. Udjeli pojedinih odgovora prikazani su u tablici 3.

Tablica 3. Stajališta o nedostatku radne snage u šumarstvu FBiH

Table 3 Attitudes on workforce shortage in forestry of FB\&H

\begin{tabular}{|c|c|c|c|}
\hline Pitanje - Question & Odgovor-Answer & $\mathrm{N}$ & $\%$ \\
\hline \multirow{4}{*}{$\begin{array}{l}\text { Nedostaje li u } \\
\text { šumarstvu FBiH } \\
\text { kvalificirane radne } \\
\text { snage? } \\
\text { Is there a shortage } \\
\text { of skilled labour } \\
\text { force in B\&H } \\
\text { forestry? }\end{array}$} & $\begin{array}{l}\text { To je izraziti problem već duže } \\
\text { vrijeme } \\
\text { This has been a significant problem } \\
\text { for a long time }\end{array}$ & 101 & 54,9 \\
\hline & $\begin{array}{l}\text { Taj je problem prisutan i bit će sve } \\
\text { veći } \\
\text { This problem is present and it will } \\
\text { increase }\end{array}$ & 75 & 40,8 \\
\hline & $\begin{array}{l}\text { Postoji taj problem, ali nije značajan } \\
\text { There is the problem, but it is not } \\
\text { significant }\end{array}$ & 5 & 2,7 \\
\hline & $\begin{array}{l}\text { Ne postoji takav problem } \\
\text { There is no such problem }\end{array}$ & 3 & 1,6 \\
\hline
\end{tabular}

Velika većina ispitanika (96\%) smatra da je problem nedostatka radne snage $\mathrm{u}$ šumarstvu $\mathrm{FBiH}$ prisutan već duže ili kraće vrijeme te da će u budućnosti biti sve izraženiji. Na slične nalaze upozoravaju i odgovori na ostala pitanja. Tako $84 \%$ svih ispitanika smatra da se većina poslodavaca susreće s problemom pronalaženja novih radnika. Kao jedan od glavnih razloga nedostatka radne snage 93 $\%$ svih ispitanika navodi odlazak radno sposobnoga stanovništva izvan $\mathrm{BiH}$. Oko $82 \%$ ispitanika ističe da radnici napuštaju šumarstvo $u$ potrazi za drugim, bolje plaćenim, lakšim i sigurnijim poslovima. 
Gotovo $80 \%$ slaže se s tvrdnjom da tomu problemu značajno pridonosi i nepovoljan demografski trend u FBiH. Samo $3 \%$ ispitanika misli da u FBiH postoji službena strategija i sustavan pristup rješavanju problema nedostatka radne snage $\mathrm{u}$ šumarstvu.

\subsubsection{Regrutiranje radnika u šumarstvu FBiH - Recruitment of forest workers in FBEH}

Ispitanici su $\mathrm{u}$ istraživanju mogli ocijeniti važnost pojedinih čimbenika za uspješnije privlačenje, tj. regrutiranje novih, mladih šumskih radnika. Nalazi pokazuju da $85 \%$ ispitanika primamljivu (konkurentnu) početnu plaću smatra značajnim čimbenikom za uspješnije privlačenje radnika. Radnici i stručnjaci u poduzećima pritom su nešto uvjereniji od njihovih kolega u institucijama da će povećanje početne plaće pridonijeti privlačenju novih radnika. Oko $89 \%$ ispitanika također navodi da veće redovite plaće uz zajamčeno povećanje plaće s godinama radnoga staža mogu dodatno privući nove radnike. Osim toga velika većina ispitanika (preko $80 \%$ ) smatra da su za snažnije regrutiranje šumskih radnika uz financijsku motivaciju vrlo važni i drugi čimbenici, npr. beneficirani radni staž, socijalna prava (radno vrijeme, godišnji odmor, osiguranje), stabilnost posla, smještaj radnika, hrana i prijevoz do radilišta, briga za zdravlje i sigurnost na poslu.

Najboljim kanalom, tj. načinom za privlačenje novih radnika, $64 \%$ ispitanika smatra potencijalne državne programe zapošljavanja. U manjoj mjeri za to se navode usmena predaja i preporuka te obrazovne institucije. Čimbenik koji bi mogao dodatno utjecati na privlačenje radnika jest osnivanje Centra za osposobljavanje šumskih radnika, što podržava $94 \%$ svih ispitanika.

Teško stanje u privlačenju radnika u šumarstvu dobro oslikavaju komentari samih sjekača, traktorista ili kopčaša, a neki od njih glase: »Teško će se radnici privući bilo čime, nitko neće u šumu, za šumarsku struku se nitko ne zanima!«; »Što god radili, teško je privući radnike za šumske poslove, to je posao nepoželjan u društvu, mladi odlaze van u potrazi za boljim poslom, a stare radnike snaga izdaje!«

\subsubsection{Zadržavanje radnika u šumarstvu FBiH i osiguranje veće predanosti poslu - Retaining forest workers in FBEH and ensuring greater job commitment}

Vezano uz zadržavanje postojećih radnika $\mathrm{u}$ šumarstvu $\mathrm{FBiH}$, preko $90 \%$ svih ispitanika drži da plaćanje radnika prema ostvarenim učincima i nagrađivanje rezultata imaju veliku ulogu $\mathrm{u}$ tome.
Gotovo jednak broj ispitanika vrlo važnim smatra ugovor o radu na neodređeno vrijeme i ostala socijalna prava radnika. Oko $83 \%$ ispitanika ističe mogućnost napredovanja i jasan budući razvojni put radnika kao bitan element za zadržavanje radnika. Među ostalim čimbenicima važnim za zadržavanje radnika često se navode: zadovoljstvo politikama i odlukama unutar poduzeća, zadovoljstvo načinom rukovođenja i menadžerima, kolegijalan odnos, otvoren dijalog i komunikacija u poduzeću, stalna briga poslodavca o zdravlju radnika, unapređenje vještina i sposobnosti radnika te uhodanost posla i ekipa na terenu. Indikativno, $80 \%$ ispitanika smatra da zadržavanje radne snage $u$ šumarstvu uvelike ovisi o zadržavanju stanovništva u ruralnim sredinama.

Za osiguranje veće predanosti radnika poslu preko $80 \%$ ispitanika vrlo važnim čimbenikom smatra stvarni interes rukovodstva za dobrobit zaposlenika. Za tim slijede ostali čimbenici, npr. konzistentni i transparentni kriteriji politike plaća, jasan opis radnih zadataka, dobra suradnja i odnosi u poduzeću, praćenje učinka i napretka radnika, dobiveno poštovanje od kolega i nadređenih te visok stupanj organiziranosti rada u poduzeću.

Dodatno, ispitanici su uz čimbenike zadržavanja radnika i predanosti poslu u istraživanju iskazali svoj stav prema mogućoj zamjeni radne snage značajnijom mehanizacijom radova odnosno uvođenjem strojne sječe. U županiji SBŽ oni uglavnom ne podržavaju rješavanje problema nedostatka šumskih radnika uvođenjem strojne sječe, dok su ispitanici u ostale dvije županije otvoreniji prema takvu rješenju. Također, $u$ odnosu na ispitanike iz institucija i poduzeća sami su šumski radnici skloniji uvođenju strojne sječe i rješenju nedostatka radne snage na taj način.

\section{Rasprava i zaključci - Discussion and conclusions}

Šumarstvo Federacije Bosne i Hercegovine nedvojbeno se suočava s problemom nedostatka šumskih radnika odnosno s izazovom osiguravanja kvalitetne i održive radne snage u šumarstvu. Rezultati provedenoga istraživanja pokazuju da je prosječna dob šumskih radnika 44 godine te da velika većina ispitanika (96\%) nedostatak radne snage smatra vrlo izraženim i sve više rastućim problemom u šumarstvu FBiH. Odlazak radno sposobnoga stanovništva izvan $\mathrm{BiH} 93 \%$ ispitanika navodi kao glavni razlog nedostatka šumskih radnika. Kao glavni nedostaci rada u šumarstvu ističu se fizički težak i visoko 
rizičan posao, koji većina radnika $(78 \%)$ nikada ne bi preporučila svojoj djeci. Više od polovice radnika pritom ne vjeruje da će se njihov položaj u skoroj budućnosti poboljšati.

Najvažnijim čimbenicima za privlačenje novih, mladih radnika u šumarstvo smatraju se primamljivija početna plaća, više redovite plaće uz zajamčeno povećanje s godinama radnoga staža te ostali čimbenici, kao što su beneficirani radni staž, socijalna i druga prava vezana uz bolje radne uvjete. Za uspješnije zadržavanja radne snage $\mathrm{u}$ šumarstvu te veću predanost poslu preko $90 \%$ ispitanika ključnim drži plaćanje radnika prema ostvarenim učincima te nagrađivanje rezultata rada. Podjednako se važnim smatraju i ostala socijalna prava radnika te općenito pozitivno okruženje u smislu zadovoljstva politikama i odlukama u poduzeću, kolegijalnoga odnosa i otvorene komunikacija, praćenja učinka i mogućnosti napredovanja radnika, stvarnoga interesa rukovodstva za dobrobit zaposlenika i dr.

Dodatno, velika većina ispitanika (94\%) drži da bi za unapređenje stanja u šumarstvu FBiH trebalo osnovati Centar za osposobljavanje šumskih radnika. Također, kao mogućnost u rješavanju pitanja nedostatka radne snage javlja se značajnija mehanizacija radova i uvođenje strojne sječe. Iznenađujuće, veću sklonost ka tomu iskazali su radnici u odnosu na stručnjake iz poduzeća i institucija svjesne složenosti takva pristupa i potrebne visokokvalificirane radne snage $\mathrm{u}$ tom slučaju.

Dobna struktura šumskih radnika značajno se razlikuje od ukupne radne snage na području $\mathrm{BiH}$, osobito u dobnoj skupini 15-24 godine. U šumarstvu udio takvih radnika iznosi 2,7 \%, dok je na razini države $7 \%$ (ASBiH 2021). To govori o većim udjelima mlađih radnika u drugim sektorima, dok $\mathrm{u}$ šumarstvu izostaje interes mladih za posao šumskoga radnika, on im nije prvi izbor, te se $u$ mnogo slučajeva za njega odlučuju jer ne mogu naći drugo zaposlenje ili su obiteljski vezani uz taj posao jer ga je obavljao i njihov otac. Također treba istaknuti da je u razdoblju od 2011. do 2019. godine više od 100000 mladih ljudi iste dobne skupine emigriralo iz $\mathrm{BiH}$ pa se brzina pada broja radno sposobnoga stanovništva znatno povećava. Učinci visokih emigracija iz BiH na domaće tržište rada pritom su još uvijek nedovoljno istraženi, iako je jasno da se radno sposobno stanovništvo smanjuje (Efendić 2021). Povezano s tim, istraživanje je pokazalo da većina šumskih radnika razmišlja o odlasku iz $\mathrm{BiH}$ i traženju istoga ili drugoga zaposlenja u drugim zemljama, ali i da rijetki od njih doista poduzimaju i konkretne korake u tom smjeru.
U Bosni i Hercegovini većina stanovništva (60\%) još uvijek živi u ruralnim sredinama, iako se male ruralne općine sve više smanjuju kako gradovi rastu (UNDP 2013). S obzirom na to da šumski radnici u pravilu dolaze iz ruralnih sredina, što pokazuje i ovo istraživanju gdje je $85 \%$ radnika iz malih ruralnih mjesta i naselja, očito je da privlačenje i zadržavanje radne snage $\mathrm{u}$ šumarstvu $\mathrm{u}$ velikoj mjeri ovisi o općem zadržavanju ljudi u ruralnim područjima. Isto je prepoznalo $80 \%$ ispitanika koji navode da iseljavanje ruralnoga stanovništva ima značajne negativne učinke na pronalaženje i zadržavanje šumskih radnika.

Osim svega navedenoga za poboljšanje položaja i stanja radne snage $\mathrm{u}$ šumarstvu $\mathrm{FBiH}$ svakako velik utjecaj imaju upravljačke i poslovne prakse šumarskih poduzeća i njihovo unapređenje. Za postizanje toga šumarskim su poduzećima potrebni uspješni i sposobni rukovoditelji koji će usmjeriti svoje znanje i energiju u donošenje kvalitetnih odluka i politika unutar poduzeća da bi izgradili pozitivno radno okruženje na dobrobit poslodavca i radnika. Pri takvu zahtjevnom zadatku državne institucije također mogu pružiti značajnu pomoć u osiguranju financiranja i provođenju raznih programa zapošljavanja, unapređenja poslovanja i poticanja investicija.

Na kraju, potrebno je istaknuti da je nedostatak radne snage $\mathrm{u}$ šumarstvu, ne samo $\mathrm{u} \mathrm{FBiH}$ nego i šire, vrlo ozbiljan i složen problem. Održivost kvalitetne i stručne radne snage $u$ šumarstvu pitanje je čije rješenje traži sustavan pristup i aktivno sudjelovanje svih uključenih dionika, u prvom redu državnih i obrazovnih institucija, šumarskih poduzeća, sindikata i ostalih važnih interesnih skupina. Rezultati ovoga istraživanja pritom mogu pridonijeti $u$ definiranju polazišta značajnih u iznalaženju učinkovitih strategija privlačenja i zadržavanja šumskih radnika te postizanju održive radne snage u šumarstvu FBiH.

\section{Literatura - References}

Ackerknecht, C., 2010: Work in the forestry sector: some issues for a changing workforce. Unasylva, 234/235, vol. 61: 60-65.

Adams, G., H. Armstrong, M. Cosman, 2014: Independent forestry safety review - An agenda for change in the forestry sector. Final report, 1-12.

ASBiH - Agencija za statistiku BiH, 2021: Saopćenje Demografija i socijalne statistike, Anketa o radnoj snazi, kvartal I 2021. godine. Godina II, broj 1, 14 str.

Axelsson, S. L., 1998: The mechanization of logging operations in Sweden and its effect on occupational safety and health. International Journal of Forest Engineering 9(2): 25-31. https://doi.org/10.1080/08435243.1998.10702715 
Bačić, M., M. Šušnjar, Z. Pandur, M. Šporčić, M. Landekić, 2018: Physical workload while working with hedging bill and battery cutter in tending of pedunculate oak. Proceedings of $7^{\text {th }}$ International Ergonomics Conference $»$ Ergonomics 2018 - Emphasis on Wellbeing «, Zadar, Croatia, June 13-16, 2018. p. 59-64.

Błuszkowska, U., T. Nurek, 2014: Effect of mechanization level on manpower needs. Folia Forestalia Polonica, series A 56(4): 194-201. https://doi.org/10.2478/ffp-2014-0022

Cacot, E., S. Grulois, A. Thivolle-Cazat, P. Magaud, 2015: Mechanization of French logging operations: challenges and prospects in 2020. Proceedings of the $48^{\text {th }}$ FORMEC Symposioum, Oct 4-8, 2015, Linz, Austria.

Nair, C. T. S., 2004: What does the future hold for forestry education. Unasylva, 216, vol. 55: 3-9.

Efendić, A., 2021: Interakcija migracija, ljudskog kapitala i tržišta rada u Bosni i Hercegovini. European Training Foundation, Report, 1-39.

Egan, A., D. Taggart, 2004: Who wil log? Occupational choice and prestige in northern New England. Journal of Forestry, 102(1): 401-406.

EU-OSHA, 2008: E-fact 29 - Occupational safety and health in Europe's forestry industry. European agency for safety and health at work, 1-13.

FAO/UNECE, 2020: Forest sector workforce in the UNE$\mathrm{CE}$ region; Overview of the social and economic trernds with impact on the forest sector. Geneva timber and forest discussion paper 76. United Nations, Geneva, 77 p.

Glavonjić, B., 2016: Belgrade State University, personal communication. In: FAO/UNECE 2020: Overview of the social and economic trernds with impact on the forest sector. Geneva timber and forest discussion paper 76, United Nations, Geneva.

Landekić, M., I. Martinić, M. Bakarić, M. Šporčić, 2013: Work ability index of forestry machine operators and some ergonomic aspects of their Work. Croatian Journal of Forest Engineering 34(2): 241-254.
Landekić M., I. Martinić, M. Bakarić, R. Ricart, M. Šporčić, 2017: Stručno osposobljavanje radnika u sektoru šumarstva - stanje u Hrvatskoj i trendovi u Europi. Šumarski list, 141(7-8): 395-407. https://doi.org/10.31298/sl.141.7-8.6

Landekić, M., S. Katuša, D. Mijoč, M. Šporčić, 2019: Assessment and comparison of machine operators' working posture in forest thinning. South-east European forestry, 10(1): 29-37. https://doi.org/10.15177/seefor.19-02

Musić, J., V. Halilović, A. Lojo, M. Šporčić, A. Đonlagić, 2019: Analiza sigurnosti pri radu u šumarstvu Federacije BiH - studij slučaja. Nova mehanizacija šumarstva, 40 : 31-41. https://doi.org/10.5552/nms.2019.4

Salminen S., T. Klen, K. Ojanen, 1999: Risk taking and accident frequency among finnish forestry workers. Safety Science, 33: 143-153. https://doi.org/10.1016/S09257535(99)00029-6

Šporčić, M., I. Martinić, M. Landekić, M. Lovrić, M. Svakidan, 2009: Prikaz stanja poduzetništva u šumarstvu srednje i istočne Europe. Nova mehanizacija šumarstva, 30: 37-46.

Šporčić, M., M. Landekić, M. Lovrić, M. Bakarić, H. Nevečerel, I. Lukec, 2015: Promjene nekih vrijednosnih kriterija šumskih radnika u 15-godišnjem razdoblju. Nova mehanizacija šumarstva, 36: 5-18.

Šporčić, M., M. Bakarić, I. Crnić, M. Landekić, 2018: Pregled dobre prakse u šumarskom poduzetništvu. Nova mehanizacija šumarstva, 39: 67-82.

Tsioras, P. A., 2010: Perspectives of the forest workers in Greece. iForest - Biogeosciences and Forestry, 3(5): 118123. https://doi.org/10.3832/ifor0547-003

Tsioras, P. A., 2012: Status and job Satisfaction of Greek Forest Workers. Small-scale Forestry, 11: 1-14. https://doi. org/10.1007/s11842-011-9164-0

UNDP - Razvojni program Ujedinjenih nacija (UNDP) u Bosni i Hercegovini, 2013: Ruralni razvoj u Bosni i Hercegovini: mit i realnost. Nacionalni izvještaj o humanom razvoju za 2013. godinu, 157 str. 


\section{Abstract}

\section{Situation of Labour Force in Forestry of the Federation of Bosnia and Herzegovina}

The Forestry of the Federation of Bosnia and Herzegovina (FBEH) undoubtedly faces the problem of forest labour force shortage, i.e. the challenge of ensuring a quality and sustainable workforce in forestry. The paper presents the findings of the survey of forestry experts and workers related to the assessment of the main characteristics and the current state of the forestry workforce in FBEH, their views on the shortage of forest workers, thoughts on opportunities and ways to recruit and retain workers in forestry, and ensure greater employees commitment to their work. The research was conducted in three cantons of FBEH (Hercegbosanska, Srednjobosanska, Unsko-sanska), and through the sample of respondents, it included three levels - personal (forest workers), company level (forest companies) and institutional (forestry administration). The results of the research indicate an average age of forest workers of 44 years and the vast majority of respondents $(96 \%)$ who consider labor shortage to be a particularly pronounced and growing problem in FBE $H$ forestry. The departure of the working age population outside the FBEH is cited by $93 \%$ of respondents as the main reason for the lack of forest workers. A more attractive starting salary, higher regular salaries with a guaranteed increase with years of service and other factors such as benefited work experience, social and other rights related to better working conditions are considered to be the most important factors for attracting new, young workers to forestry. About $94 \%$ of respondents believe that a training center for forest workers should be established to improve the situation in BEH. Over $90 \%$ of respondents consider the payment of salaries according to the achieved effects and rewarding according to results necessary for retaining the workforce in forestry and ensuring greater commitment of workers to their work. Equally important are other social rights of workers and a generally positive atmosphere in terms of employers making and implementing business decisions and policies. Given that this is a very complex problem, the sustainability of a quality workforce in FBEH forestry is an issue that requires a systematic approach and active participation of all stakeholders, primarily state and educational institutions, forest companies, unions and other interested parties. The results of this research can contribute to defining starting points important in finding effective strategies for attracting and retaining forest workers and providing a sustainable workforce in FBEH forestry.

Keywords: forestry, forest workers, labor shortage, recruiting workers, Federation of Bosnia and Herzegovina

Primljeno (Received): 17. 9. 2021.

Prihvaćeno (Accepted): 13. 10. 2021.
Adrese autorâ - Authors' addresses:

David Mijoč, dipl. ing. šum.

e-pošta:dmijoc@gmail.com

ŠGD Hercegbosanske šume d.o.o. Kupres

Splitska bb

80320 Kupres

BOSNA I HERCEGOVINA

Prof. dr. sc. Mario Šporčić*

e-pošta:msporcic@sumfak.unizg.hr

Doc. dr. sc. Matija Landekić

e-pošta: mlandekic@sumfak.unizg.hr

Sveučilište u Zagrebu

Fakultet šumarstva i drvne tehnologije

Svetošimunska cesta 23

10000 Zagreb

HRVATSKA

* Glavni autor - Corresponding author 